\title{
ON AEROMONAS HYDROPHILA INFECTION AMONG CULTURED TILAPIAS : A BIOLOGICAL, HISTOPATHOLOGICAL AND MANAGEMENT STUDY
}

\author{
Ahmed M. M. El-Ashram \\ Fish Diseases Dept., Central Laboratory for Aquaculture Research \\ (El-Abbassa), Agricultural Research Center, Egypt.
}

Key words: Aeromonas hydrophila, tilapia, histopathology, biology, management, Oxytetracycline, vaccine.

\section{ABSTRACT}

$\mathrm{T}$ The prevalence of Aeromonas hydrophila infection, the causative agent of motile Aeromonas septicemia, was $47.3 \%$ among the diseased cultured tilapias. Oreochromis niloticus was the more sensitive species to MAS. MAS infected tilapia showed loss of balance, reduced growth, fins and tail rot, ulcer and enlargement of the abdomen. Internally, the organs were congested. The intraperitoneal route was more pathogenic than intramuscular one in the experimentally infected $O$. niloticus. Microscopically different organs showed histopathological changes.

Also, changes in serum biochemical parameters were recorded. The antibacterial activity of Oxytetracyclin (OTC) was evaluated both invitro and in vivo. OTC was the drug of choice for the control and prevention of MAS under laboratory and field conditions. Immunization of tilapia with formalin-killed whole culture vaccine through intraperitoneal route gave successful results.

\section{INTRODUCTION}

Tilapia fish are likely to be the most important of all cultured fish in the $21^{\text {st }}$ century. They are farmed in every manner from semiextensive to super-intensive farms (Fitzsimmons, 2000).

Infectious diseases of cultured fish are among the most notable constraints on the expansion of aquaculture and the realization of its full potential (Plumb, 1999; Woo and Bruno, 1999 and Klesius et al., 2000). Bacterial pathogens are the most serious disease problem in tilapia production causing $80 \%$ of fish mortalities (Plumb, 1999; Woo and Bruno, 1999; Clark et al., 2000; Shoemaker et al., 2000). 
Motile Aeromonas Septicemia (MAS) is a more drastic one and distributed world-wide, affecting various species of fish and shellfish, feral as well as farmed fish in both freshwater and sea water, (Inglis et al., 1993; Austin and Austin, 1993; Plumb, 1999; Woo and Bruno, 1999; Fang et al., 2000; Aly et al., 2000 and Azad et al., 2001). MAS is a serious problem for the fish farming industry in Egypt as well as in other countries. The causative agent of MAS, Aeromonas hydrophila, is also an opportunistic pathogen of humans causing illness that ranged from mild to dysentery-like diarrhea to meningitis and septicemia particularly when fish is eaten raw or improperly cooked (Inglis et al., 1993). Also, the external clinical signs of the affected fish make them unmarketable.

During the last decade, the interest in protection against fish diseases has grown enormously (Lamers et al., 1985). The lack of effective disease control has the potential of being the chief limiting factor of the realization of highly stable tilapia production (Klesius et al., 2000). The use of vaccines and antibiotics are the two available direct methods to protect farmed fish against diseases. Antibiotics alone will not be enough, but they still have an important role to play in good health management practices (Tafalla et al., 1999 and Clark ef al., 2000). Disease prevention by the use of vaccines is the most effective means to reduce disease losses and ensure healthy tilapia production in the new century (Clark et al., 2000 and Klesius et al., 2000).

Therefore, the current investigation was planned to throw light on Motile Aeromonas Septicemia as a major disease among cultured tilapias species, as well as the optimal preventive trials to control the disease.

\section{MATERIAL AND METHODS}

Naturally Infected Fish: A total number of 150 clinically and grossiy diseased tilapia species (50 of each Oreochromis niloticus, Oreochromis aureus and Sarotherodon galilaeus) were collected from different fish farms and transferred to the Central Laboratory for Aquaculture Research, El-Abbassa, Sharkia, Egypt. The diseased fish were subjected to full clinical and postmortem examinations as described by Amlacher (1970) and Lucky (1977).

\section{Bacteriological Examination:}

Samples were taken under complete aseptic condition from the affected areas of the external body (fins, tail and gills) and from the 
internal organs (liver, spleen, kidney and gonads) and inoculated into tryptic soya broth (Difco) and incubated at $25^{\circ} \mathrm{C}$ for 24 hours, then further identification by standard microbiological procedures according to Schaperclaus et al., (1992).

\section{Experimental Fish :}

$O$. niloticus was chosen for experimental studies as they are more sensitive species to MAS and the more popular cultured fisl.

A total number of 210 apparently healthy $O$. niloticus were collected from El-Abbassa fish ponds and transferred alive to the laboratory to be used in the artificial infection, laboratory trial for Oxytetracyclin and vaccination. Fish were acclimatized to laboratory conditions for 2 weeks, maintained at $25 \pm 1{ }^{\circ} \mathrm{C}$ in glass aquaria supplied with well-aerated, dechlorinated water. During this time and throughout the experiment, they were fed at $2 \%$ of their body weight per day, divided into two diets.

\section{Histopathological Examination:}

Samples from affected organs and tissues of naturally infected fish were fixed in $10 \%$ phosphate buffered formalin. Parafin sections ( $5 \mu$ thick) were prepared and stained with hematoxylin and eosin (H\&E) and examined microscopically (Roberts, 1989).

\section{Experimental Infection:}

A total of 60 apparently healthy $O$. niloticus were divided into 3 equal groups. $0.2 \mathrm{ml}$ dose of $24 \mathrm{hr}$. broth culture from virulent previousiy isolated bacterial pathogen of $A$. hydrophila $\left(5 \times 10^{5}\right.$ $\mathrm{CFU} / \mathrm{ml}$ ) were given by intramuscular (i.m.) and intraperitoneal (i.p.) injection for the first and second groups respectively (Schaperclaus et al., 1992). The third group was kept as a control and inoculated with sterile broth (10 fish i.m. \& 10 fish i.p.). All the experimentally infected fish were daily noticed for any abnormal clinical signs and mortalities. The dead and clinically diseased fish were subjected to bacterial re-isolation and histopathological examination.

\section{Sensitivity test:}

The antibiograms of the recovered pathogen were done using the disc diffusion method. The interpretations of zones of inhibition were estimated according to the limits given by Biomerieux (1984).

\section{Laboratory efficacy trial of Oxytetracyclin (OTC):}

A laboratory trial was performed to determine the effect of OTC against infection of $O$. niloticus with $A$. hydrophila (Bowser et al., 1994 and Tafalla et al., 1999). A total number of 30 apparently healthy $O$. niloticus were divided into 3 equal groups. The medicated 
diet was prepared by adding powdered OTC at $75 \mathrm{mg} / \mathrm{kg}$ fish/day for 10 days (Plumb, 1999). The first group received medicated diet and inoculated i.p. with $A$. hydrophila. The second group received nonmedicated ration and challenged with $A$. hydrophila. The third group was left as a control, receiving. non-medicated ration and non challenged. During the $10-\mathrm{d}$ medication period and 15-d postmedication, any adverse clinical signs and mortalities were recorded. All fish were examined for the presence of $A$. hydrophila:

Field evaluation of OTC:

A private farm for intensive production of tilapia suffered from MAS as indicated by our examination was subjected for treatment with OTC (Plumb, 1999). Hygienic disposal of dead fish was done.

\section{Biochemical changes associated with Aeromonas hydrophila infection:}

Thirty 0 . niloticus were used in this experiment. 10 fish were injected with saline and kept as a control. A total 20 fish were injected i.p. with $A$, hydrophila. Blood samples were collected from clinically diseased tilapia on 3 day post-injection, Biochemical assays were conducted according to Wotton and Freeman (1982).

\section{Vaccine and Vaccination:}

Formalin-killed whole culture vaccine was prepared from virulent isolates of $A$. hydrophila used in experimental infection as described by Badran (1987). The sterility and safety. tests were performed according to Cardella and Eimers (1990). For parental vaccination, 600 . niloticus weighing from $60-80 \mathrm{gm}$ were injected i.p. with $0.2 \mathrm{ml}$ of bacterin. A parallel group of control fish (30) was injected with saline. After 2-4-6 weeks, a challenge infection was done as mentioned by Badran (1987). All the challenged fish (20 of each time) were placed under observation for $21-d$, during which the mortality was monitored and the specificity of death was determined by re-isolation of $A$. hydrophila from morts.

The potency of vaccine was expressed as relative percentage of survival (RPS) using the formula of Cardella and Eimers (1990). The obtained results were statistically analyzed according to Hill (1977).

\section{RESULTS}

The prevalence of $A$. hydrophila infection was $47.3 \%$ among the diseased tilapia species. The percentages of infection in $O$. 
niloticus, $O$. aureus and $S$. galilaeus were 66,42 and 34 respectively (Table 1).

MAS infected fish showed loss of their appetite, dullness, loss of equilibrium, sluggish swimming at the water surface, detachment of scales, skin erosion and ulcer. The ulcers were usually shallow. Some infected fish had exophthalmia accompanied by hemorrhage or opaqueness of the eye. Fin and tail rot, enlarged abdomen with ascites and if the vent was involved, it might also prolapse. Gills might be congested or pale and anaemic and covered with excessive mucus. The anal and genital regions were also swollen and hyperemic and sometimes small ulcer was noticed near them, other cases showed reddish mouth (Fig. 1).

Internally, the organs were friable and showed a generalized hyperemic appearance (Fig. 2). The liver varied from yellow to dark brown in colour with necrotic foci in some cases and in association with over distended gall bladder with bile. The body cavity contained a bloody and cloudy fluid. The intestine was flaccid, hyperemic, contained yellowish mucus and voided of food. The kidney and spleen were swollen and congested. The gonads were congested, swollen and with abnormal colour in some cases.

A. hydrophila appeared to be Gram-ve, of short motile rods, and cytochrome oxidase positive (Table 2 ).

The distribution of $A$. hydrophila in various tissues and organs of diseased tilapia was demonstrated in Table (3), where a higher percentage was reported from tail and fins $(30.17 \%)$ followed by gills $(20.11 \%)$. The lowest was recorded from the ascitic fluid $(3.35 \%)$.

Experimentally infected $O$. niloticus showed nearly similar clinical signs, with postmortem and histopathological changes to those observed in naturally infected ones. Table (4) showed mortalities pattern among the artificially inoculated fish with previously isolated $A$. hydrophila from naturally infected fish. The i.p. route infection produced a higher mortality than the i.m. route. Re-isolation of $A$. hydrophila was succeeded. from all dead and clinically diseased fish. On the contrary, the control group showed neither clinical signs nor mortalities. Furthermore, no $A$. hydrophila was isolated from the control group.

Histopathologically, the infected $O$. niloticus showed desquamation of the upper layer of epidermis with increased number of melanin carrying cells and hyperplasia of mucous cells (Fig. 3). The gills of infected tilapia showed desquamation of epithelial 
covering of gills lamellea associated with separation of gill filament (Fig. 4). The liver revealed marked congestion of the central vein (Fig. 5). Also, liver showed infiltration of pancreatic acini by melanomacrophages (Fig. 6). The kidneys showed severe hyaline droplet degeneration (Fig. 7) and coagulative necrosis of renal tubules (Fig. 8).

Regarding to the sensitivity of $A$. hydrophila to different antimicrobials, the bacterial isolates were sensitive to Oxytetracycline, Trimethoprim, Chloramphenical, Nalidixic acid, Neomycin and Erythromycin. On the other hand, it was noticed that A. hydrophila was resistant to Penicillin G, Nitrofurantion and Amoxicillin.

The laboratory trial indicated that the Oxytetracycline incorporated into feed at a dose of $75 \mathrm{mg} / \mathrm{kg}$ fish/day for 10 days was quite effective against MAS (Table 5). Survival of fish medicated challenged or non-medicated non-challenged were higher than that non-medicated challenged fish. No $A$. hydrophila was detected from any fish that survived to the end of the trial in both medicated challenged and non-challenged. groups. On the other hand, $A$. hydrophila was isolated from fish that have died during the trial from challenged- non medicated group.

In the field, OTC was found to control MAS successfully when administered at a rate of $75 \mathrm{mg} / \mathrm{kg}$ body weight / day for 10 days, where mortalities were declined. Also, the clinical signs were disappeared and the fish returned to normal state of health. Meanwhile, A. hydrophila was not isolated from fish after treatment.

With regard to the effect of $A$. hydrophila infectivity on $O$. niloticus, the present results. (Table 6) showed a significant differences in hemoglobin $(\mathrm{Hb})$ concentration in-between the control and infected groups. Also, there was a significant decrease in giucose level of the infected group. On the other hand, a liver dysfunction was indicated by a significant increase of both the aspartate transferase (AST) and alanine transferase (ALT) activities. There was nonsignificant decrease in the total protein.

In the trial of vaccination experiment, table (7), showed the result of immunization of $O$. niloticus fish against $A$. hydrophila using formalin-killed whole culture vaccine through i.p. route. The relative survival percentages were 95,100 and $100 \%$ on challenge at $2,, 4$ and 6 weeks post-vaccination, respectively. while, the control group had $100 \%$ mortality. 


\section{DISCUSSION}

The causative agent of MAS, $A$. hydrophila, has a worldwide distribution, infecting fishes, birds as well as human. Moreover, MAS is a serious problem for the fish farming industry in Egypt, causing heavy economic losses.

The high prevalence of $A$. hidrophila could be attributed to its presence as a part of intestinal flora of healthy freshwater and marine fish (Newman, 1982; Austin and Austin, 1993 and Plumb, 1999). The present results showed that $A$. hydrophila was the most predominant bacterial species isolated from diseased fish. These results agree with those recorded by Abd El-Rahman (1996) and Sakr (1996) who mentioned that MAS comes first among the diseases infecting fish. Also, there were differences in the susceptibility of tilapias to MAS. Abd El-Rahman (1996) and Abd El-Rahman et al, (2002) cited that $T$. zilli and $S$. galilaeus had higher resistance to bacterial diseases relatively than other tilapias, as $T$. zillii can live at a lower temperature and a higher water salinity than other tilapias.

Regarding to the clinical signs, it was revealed that fish infected with $A$. hydrophila showed loss of equilibrium, fin and tail rot, ulcer and enlargement of abdomen. These results accord with those recorded by Enany et al., (1985); Kabata (1985); Post (1987); Austin and Austin (1993); Inglis et al., (1993); Newman (1993); Stoskoph (1993); Ahmed et al., (1995), Sakr (1996); Abd El-Rahman (1996); Plumb (1999); Woo and Bruno (1999); Shoemaker et al., (2000); Fang et al., (2000) and Azad et al., (2001) who mentioned that the sluggish movement associated with $A$. hydrophila infection was probably the result of frayed and sloughed tail, beside hemorrhagic edematous and ulcerated fins, in addition to anorexia which affected the vital activities of the diseased fish.

The common gross lesions observed in the diseased fish were septicemia in nature as they revealed congestion of all internal organs with abdominal distension and yellowish ascitic fluid. The postmortem lesions were in accordance with the findings of Amlacher (1970); Newman (1982); Enany et al. (1985); Kabata (1985); Post (1987); Roberts (1989); Stoskoph (1993); Inglis et al., (1993); Abd El-Rahman (1996); Sakr (1996); Plumb (1999); Woo and Bruno (1999); Shoemaker et al., (2000) and Azad et al., (2001) that the overdistended gall bladder could be attributed to enteritis and constriction of the common bile duct. Also, the gills were severely 
congested and the fins were congested and hemorrhagic. However, many other bacterial infection in tilapia cause the same or similar clinical signs and post-mortem lesions (Plumb, 1999 and Clark et al., 2000) it was therefore considered prudent to make isolates from various tissues of moribund fish.

The morphological and biochemical investigations revealed that A. hydrophila was $\mathrm{G}$-ve, with short motile rods and comparable to that recorded by Enany et al. (1985), Kabata (1985); Post (1987); Austin and Austin (1993); Inglis et al, (1993); Ahmed et al., (1995); Abd El-Rahman (1996); Plumb (1999) and Woo Bruno (1999).

The highest recovery rate of $A$. hydrophila suggested that tail and fins $(30.17 \%)$ could be the primary entrance for systemic infection as suggested by Enany et al. (1985); Sakr (1996) and Azad et al. (2001).

The artificial infection, in the present study showed that the i.p. route was more pathogenic than i.m. one. Also, the same clinical signs, postmortem and microscopic findings were similar to that of naturally infected tilapia as reported by Newman (1982); Enany ef al. (1985); Kabata (1985); Post (1987); Roberts (1989); Stoskoph (1993); Ahmed et al. (1995); Sakr (1996); Abd El-Rahman (1996); Plumb (1999) and Azad et al. (2001).

Moreover, similar histopathological changes in the infected fish were observed by Amlacher (1970); Kabata (1985); Miyazaki and Kaige (1985); Post (1987); Roberts (1989); Inglis et al. (1993), Ahmed et al. (1995); Sakr (1996); Plumb (1999); Aly et al. (2000) and Azad et al. (2001).

It was shown also that OTC was the drug of choice for the treatment of infected $O$. niloticus from MAS, both in-vitro and invivo and under both laboratory and field conditions. Similar results were recorded by Kabata (1985); Post (1987); Saleh and El-Naenaeey (1990); Badran (1993); Austin and Austin (1993); Eissa et al. (1993), Thorpurn and Moccia (1993); Abd El-Rahman (1996); Tafalla et al. (1999) and Plumb (1999) who mentioned that OTC has proved a world-wide efficacy to control or treat MAS infection in fish.

However, Shoemaker et al. (2000) found that antibiotic treatments had not been effective in eleminating bacterial problems in water re-use systems. They added that a part of the problem with current antibiotic use was that at the time of intervention, the fish were often so sick that they did not eat the medicated feed or that treatments were not of long enough duration. The extensive use of 
antibacterials has led to an increase in resistant strains of $A$. hydrophila (Woo and Bruno, 1999).

With respect to the use of hematological parameters and enzyme activities in the early diagnosis of infection, the present results showed marked reduction in $\mathrm{Hb}$, and glucose, while a non significant decrease in total protein was noticed. Liver dysfunction was indicated by significant increase in AST and ALT. Similar findings were reported by Amlacher (1970); Sauer and Haider (1977); Enany et al., (1985); Wakabayashi and Iwado (1985); Mohamed (1987) and Husien and Elias (2000), who reported a destruction of haematopoietic tissues and decrease in blood cell production in infected fish. Also, the progressive loss of serum protein and glucose might be attributed to the increased permeability of renal glomerular capillaries induced by the bacterial toxin.

Nowadays, many commercially available bacterins are used for vaccination against various fish diseases (Newman, 1993). Diseases prevention by the use of vaccine is the most effective means to reduce disease losses and ensure healthy tilapia production (Klesius et al., 2000). The immunization of $O$. niloticus with formalized whole culture vaccine of virulent strains $A$. hydrophila appeared to be more effective and economic for controlling MAS out break among cultured tilapia in Egypt. The non-immunized fish of the control group showed higher mortalities than the immunized ones after challenge. Previous studies showed that i.p. injection of $A$. hydrophila was effective in protecting fish against infection (Newman, 1982; Lamers et al., 1985; Badran, 1987; Stevenson, 1988; Austin and Austin, 1993; Inglis et al., 1993; Ahmed et al., 1995; Plumb, 1999; Woo and Bruno, 1999; Aly et al., 2000; Clark et al., 2000 and Klesius et al., 2000). On the other hand, Lamers et al., (1985) reported that oral application of vaccines was not always effective. Fang et al., (2000) recorded that the bactericidal activity of the specific antisera against virulent and avirulent strains of $A$. hydrophila were different. However, vaccines should not be viewed as a panacea for all ills (Clark et al., 2000). According to Austin and Austin (1993), proper management is essential to success of aquaculture operations, while the inadequate management is the principal factor in triggering disease outbreaks. 


\section{REFERENCES}

Abd El-Rahman, A. M. (1996). Studies on bacterial diseases among cultured tilapia. M. V. Sc. ; Fish Dis. Dept. ; Suez Canal Univ.

Abd El-Rahman, A. M. ; El-Nobi, G. and Moustafa, A. (2002). Studies on Pseudomonas septicemia among tilapia fish in Abbassa fish farms. Zag. Vet. J., 30(1) 25-34.

Ahmed, S. A.; Marzouk, M. S. ; Megid, R. M. A. ; Moustafa, M. and Gado, M. (1995). Histopathological and immunological studies on Aeromonas hydrophila infection in common carp. Vet. Med. J., Giza, 43 (4): 389 - 396.

Aly, S. M. ; Tantawy, H. M. ; Badran, A. F. and El-Baz, M. A. (2000). Histopathologic and immunologic respense of Clarias lazera to the injection of Aeromonas hydrophila vaccine. Suez Canal Vet. Med. J., 111 (1): 133 - 144.

Amlacher, E. (1970). Text book of fish diseases. Gustav Fisher Verlag, Tena DDR.

Austin, B. and Austin, D. A. (1993). Bacterial Fish Pathogens. In Disease in Farmed and wild fish. Ellis Horwood Ltd. Publisher, Chichester, England.

Azad, I. S. ; Rajendran, K. V. ; Rajan, J. S. ; Vijayan, T. C. and Santiago, T. C. (2001). Virulence and histopathology of Aeromonas hydrophila (SAH. 93) in experimentally infected tilapia, Oreochromis mossambicus (L.). J. Aqua. Trop., 16 (3): 265-275.

Badran A. F. (1987). Trials for control of Aeromonas hydrophila infection among Egyptian cultured fresh water fish. $\mathrm{Ph}$. D. Thesis, Fac. Vet. Med., Zag. Univ.

Badran, A. F. (1993). An outbreak of Edwardseillosis among Nile tilapia (Oreochromis niloticus) reared in ponds supplied with domestic wastewater. Zag. Vet. J., 21 (5): $771-778$. 
Bio-merieux, (1984). Laboratory reagents and products. Bacterial. Barcy-L. Etiole 69260 charbonmieres-Les-Bains. France.

Bowser, P. R. ; Wooster, G. A. and Hsu, H. (1994). Laboratory efficacy of enrofloxacin for the control Aeromonas solmanicida infection in rainbow trout. J. Aq. Anim. Health, $6: 288-291$.

Cardella, M. A. and Eimers, M. E. (1990). Safety and potency testing of fedral licensed fish bacterins. J. Aq. Anim. Health, 2: 49 -55 .

Clark, J. S. ; Pallers B. and Smith, P. D. (2000). Prevention of Streptococcus in tilapia by vaccination the Philippine excperiences. $5^{\text {th }}$ Int. Symposium on tilapia aquacult. in the 21 st century. Brazil, 2: 545-552.

Eissa, I. A. M. ; Badran, A. F. and Hanafi, M. S. (1993). Control of diseases problems among cultured freshwater fishes in Kafi El-Sheikh Governorate J. Egypt. Vet. Med. Ass., 53(3): 505-512.

Enany, M. ; Nareeman, E. ; Abd El-Galil, Y. and Ammar, A. M. (1985). Aclinico-pathological study of Aeromoniasis in experimentally inoculated Armout cat fish. Fist lnt. conf. App. Sci., 4: 1753-1767.

Fang, H. M. ; Ling, K. C. ; Ge, R. and Sin, Y. M. (2000). Enhancement of protective immunity in blue gourami, Trichogaster trichopterus (Pallas), against Aeromonas hydrophila and Vibrio anguillarum by $A$. hydrophila major adhesin. J. Fish Diseases, 23(1) 137-145.

Fitzsimmons, K. (2000). Tilapia the most important aquaculture species of the $21^{\text {st }}$ century. $5^{\text {th }}$ Int. symposium on tilapia aquaculture in the $21^{\text {st }}$ century. Brazil, $1: 3-8$.

Hill, A. B. (1977). Textbook of Medical statistics. $10^{\mathrm{d}_{3}}$ ed, English Lang. Soc., Hodder \& stoughton, London. 
Husien, M. M. and Elias, N. S. (2000). The role of comparative analysis for enzymatic efficacy with blood picture in early diagnosis of some bacterial freshwater fish diseases. Suez Canal Vet. Med. J., III (2): 625 - 634.

Inglis V.; Roberts, R.S. and Bromage, R. (1993): Bacterial diseases of fish. $1^{\text {st }}$ ed. Halsted Press New York.

Kabata, Z. (1985). Parasites and diseases of fish cultured in the tropics. (ed. By Taylor and Francis) London and Philadelphia, Int. Dev. Res. Co. $1^{\text {st }}$ Ed.

Klesius, P. H. ; Shoemaker, C. A. and Evans, J. J. (2000). Vaccination. A health management practice for preventing diseases in tilapia and other cultured fish. $5^{\text {th }}$ Int: symposium on tilapia aquaculture in the $21^{\text {st }}$ century. Brazil, 2:558-564.

Lamers, C. H. J. ; Dehaas, M. J. M. and Van Muiswinkle, W. B. (1985). Humoral response and memory formation in Carp, Cyprinus carpio after injection of $A$. hydrophila bacterin. Develop. Comp. Immunol., 9: 65-76.

Lucky, Z. (1977). Methods of the diagnosis of Fish diseases. Amerind Publ. Co. PVT 1td., New Youk, $1^{\text {st }}$ Ed.

Miyazaki, T. and Kaige, N. (1985). A histopathological study on motile aeromonal disease of crucian carp. Fish Pathology, 21:181-185.

Mohamed, K. E. (1987). Biochemical studies on some freshwater fish subjected to infection with Aeromonas hydrophila. M. V. Sc., Biochemicstry Dept., Zag. Univ.

Newman, S. G. (1982). Aeromonas hydrophila : A review with emphasis on its role in fish diseases. In Antigens of fish pathogens. Development and production for vaccine and serodiagnositics, ed. D.P. Anderson, M. Dorson and PhDubouret, pp : 87 - 117 lyon : foundation Marcel Merieux. 
Newman, S. G. (1993). Bacterial vaccines for fish. Annual Review of fish Diseases, 3:145-185.

Plumb, J. A. (1999). Health maintenance and principai microbial diseases of cultured fishes. Iowa state Press. U.S.A.

Post, G. (1987). Textbook of fish health T.F.H. publ, Inc Ltd., U.S.A.

Roberts, R. J. (1989). Fish Pathology. Sailliere Tindal, London.

Sakr, S. F. (1996). Prevalence of Pathological changes associated with the fin-rot inducing bacterial diseases in fresh water fish. M.V. Sc., Pathology Dept., Fac. Vet. Med., Zag. Univ.

Saleh, G. and El-Naenaeey, E. (1990). Pre liminary observation on motile aeromonad disease in Guppy ornamental fish (Poecilia reticulata) and methods of treatment. Zag. Vet. J., 17(5): 17-28.

Sauer, D. M. and Haider, G. (1977). Enzymes activities in the serum of Rainbow trout. J. Fish Biol., 11:605-612.

Schaperclaus W. ; Kulow H. and Shreckenbach K. (1992). Fish Diseases, Vol. I. A. A. Balkema Rotterdam.

Shoemaker, C. A. ; Klesius, P. H. and Evans, J. J. (2000). Disease of tilapia with emphasis on economically important pathogens. $5^{\text {th }}$ Int. symposum on tilapia aquaculture in $21^{\mathrm{st}}$ century, Brazil, 2: 565-572.

Stevenson, R. M. W. (1988). Vaccination against Aeromonas hydrophila. In : Ellis, A: E. (ed.) fish vaccine. Academic press, London, pp. 122-123.

Stoskoph M. (1993). Fish Medicine. W. B. Saunders Co., U. K.

Tafalla, C. ; Novoa, B. ; Alvarez, J. M. and Figueras, A. (1999). In vivo and in vitro effect of Oxytetracycline treatment on the immune response of turbot, Scophthalmus maximus. J. Fish Dis., 22:271-276. 
Thorpurn, M. A. and Moccia, R. D. (1993). Use of chemotherapeutics on trout farms in Ontario J. Aq. Anim. Health, $5: 85-91$.

Wakabayashi, H. and Iwado (1985). Changes in glycogen, pyruvate and lactate in Rainbow trout with bacterial gill disease. Fish Pathology, 20(213): 161-165.

Woo, P. T. K. and Bruno, D. W. (1999). Fish diseases and disorders. Vol. 3, Viral, Bacterial and Fungal. infections. CABI pubiishing, , London, U. K.

Wotton, I. D. and Freeman H. (1982). Micro analysis in Medical Biochemicsty. Churchill, Livingstane, Edinburght, London and New York. 
Table (1): The prevalence of MAS in tilapias fish.

\begin{tabular}{|l|l|l|l|}
\hline \multirow{2}{*}{ Species } & \multirow{2}{*}{ No. of examined } & \multicolumn{2}{|l|}{ MAS } \\
\cline { 3 - 4 } & & No. & $\%$ \\
\hline O. niloticus & 50 & 33 & 66 \\
O. aureus & 50 & 21 & 42 \\
S. galilaeus & 50 & 17 & 34 \\
\hline Total & 150 & 71 & 47.3 \\
\hline
\end{tabular}

Table (2): Cultural and biochemical reactions of $A$. hydrophila isolated from naturally infected tilapia.

\begin{tabular}{|l|l|l|l|}
\hline Test & Reaction & Test & $\begin{array}{l}\text { Reactio } \\
\mathrm{n}\end{array}$ \\
\hline Gram stain & -ve & Cytochrome & + \\
Shape & shoit rod & oxidase & + \\
Motility & + & Indole production & + \\
Growth on R-S media & yellow & Voges-Proskauer & - \\
Oxidation-fermentation & colonies & Nitrate reduction & + \\
$\mathrm{H}_{2}$ S production & $\mathrm{F}$ & Methyl red & + \\
Ferinentation of & - & Gelatin & \\
Glucose & & liquefaction & - \\
Manital & + & & + \\
sucrose & + & Lactose & + \\
& + & Fructose & \\
\hline
\end{tabular}


Table (3) : The percentage of $A$. hydrophila from various tissues and organs of naturally infected tilapia.

\begin{tabular}{|c|c|c|c|c|c|c|c|c|c|c|c|c|c|c|}
\hline \multirow{2}{*}{ Fish species } & \multicolumn{2}{|c|}{ Tail \& fins } & \multicolumn{2}{|c|}{ Gills } & \multicolumn{2}{|c|}{ Liver } & \multicolumn{2}{|c|}{ Kldacy } & \multicolumn{2}{|c|}{ Spleed } & \multicolumn{2}{|c|}{ Ascitic fluid } & \multicolumn{2}{|c|}{ goneds } \\
\hline & No. & $\%$ & No. & $\%$ & No. & $\%$ & No. & $\%$ & No. & $\%$ & No. & $\%$ & $\mathrm{No}$. & $\%$ \\
\hline o. nilloticus & 19 & 29.23 & 12 & 18.46 & 11 & 16.92 & II & 16,92 & 4 & 6.15 & 3 & 4.62 & 5 & 7.69 \\
\hline O. aureus & 17 & 28.81 & 13 & 22.03 & 10 & $16.9 \mathrm{~J}$ & 9 & 15.25 & 3 & 8.47 & 2 & 3.39 & ? & 5,08 \\
\hline S. gallineus & 18 & 32.73 & 11 & 20 & $n$ & 20 & 10 & 18.18 & 4 & 7.27 & i & 0.56 & 0 & 0 \\
\hline Total & 54 & 30.17 & 36 & 20.11 & 32 & {$[7.88$} & 30 & 16.76 & 13 & 7.26 & 6 & 3.35 & 8 & 4.47 \\
\hline
\end{tabular}

Table (4) : Mortality rates among $O$. niloticus artificially inoculated with $A$. hydrophila.

\begin{tabular}{|c|c|c|c|c|}
\hline Fish Group & Rout of injection & No. of fish & No. of dead & Mortality rate \\
\hline I & i.m. & 20 & 14 & 70 \\
II & i.p. & 20 & 18 & 90 \\
III & i.m. & 10 & 0 & 0 \\
& i.p. & 10 & 0 & 0 \\
\hline
\end{tabular}

Table (5) : Laboratory efficacy of Oxytetracyclin for the control of $A$. hydrophila infection.

\begin{tabular}{|l|c|c|c|}
\hline Fish Group & No. of fish & No. of dead & $\%$ of survival \\
\hline Group 1 (OTC-bacteria challenged) & 10 & 2 & 80 \\
Group 2 (No OTC-challenged) & 10 & 9 & 10 \\
Group 3 (No OTC-Non-challenged) & 10 & 0 & 100 \\
\hline
\end{tabular}




\section{CULTURED TILAPIAS}

Table (6) : Hemoglobin and some serum biochemical parameters in $O$. niloticus infected with $A$. hydrophila.

\begin{tabular}{|c|c|c|}
\hline Item & $\begin{array}{c}\text { Control } \\
\text { Mean } \pm \text { S.E. }\end{array}$ & $\begin{array}{c}\text { Infected } \\
\text { Mean } \pm \text { S.E. }\end{array}$ \\
\hline $\begin{array}{c}\text { Hb. } \\
\text { gm/dl) } \\
\text { glucose } \\
(\mathrm{mg} / \mathrm{dl})\end{array}$ & $7.81^{\mathrm{a}} \pm 0.28$ & $5.90^{\mathrm{b}} \pm 0.16$ \\
$\begin{array}{c}\mathrm{AST} \\
(\mathrm{iu} / \mathrm{ml})\end{array}$ & $51.97^{\mathrm{a}} \pm 1.54$ & $38.15^{\mathrm{b}}+2.38$ \\
$\mathrm{ALT}$ & $48.46^{\mathrm{a}} \pm 1.50$ & $57.51^{\mathrm{b}}+1.24$ \\
$\begin{array}{c}\text { (iu/ml) } \\
\text { Total Protein } \\
(\mathrm{gm} / \mathrm{d})\end{array}$ & $41.75^{\mathrm{a}} \pm 0.50$ & $49.40^{\mathrm{b}} \pm 0.90$ \\
\hline
\end{tabular}

Means with the same letter are not significantly different.

$\mathrm{P}<0.05$

Table (7) : Showing results of vaccination trial against $A$. hydrophila via intraperitoneal route in $O$. niloticus.

\begin{tabular}{|l|c|c|c|c|c|c|}
\hline Fish group & \multicolumn{3}{|c|}{ Control } & \multicolumn{3}{c|}{ vaccinated } \\
\hline Time & $2 \mathrm{w}$ & $4 \mathrm{w}$ & $6 \mathrm{w}$ & $2 \mathrm{w}$ & $4 \mathrm{w}$ & $6 \mathrm{w}$ \\
\hline No. of injected & 10 & 10 & 10 & 20 & 20 & 20 \\
\hline R.P.S. & - & - & - & $95 \%$ & 100 & 100 \\
\hline
\end{tabular}




\section{LEGEND OF FIGURES}

Fig. 1: Tilapias infected by $A$. hydrophila showing hemorrhage, scales loss, erosion, corneal opacity and frayed tail.

Fig. 2: Tilapia infected by $A$. hydrophila showing congested internal organs and abdominal ascites.

Fig. 3: O. niloticus infected with $A$. hydrophila, fin showing desquamation of upper layer of the epidermis which infiltrated with melanin carrying cells and hyperplasia of mucous cells. $\mathrm{H} \& \mathrm{E}, \mathrm{x} 60$.

Fig. 4: O. niloticus infected with $A$. hydrophila, gills showing desquamation of epithelial covering of gills lamellea and separation of gill filament. $\mathrm{H} \& \mathrm{E}, \mathrm{x} 60$.

Fig. 5: O. niloticus infected with $A$. hydrophila, liver showing congested central vein $\mathrm{H} \& \mathrm{E}, \mathrm{x} 60$.

Fig. 6: $O$. niloticus infected with $A$. hydrophila, liver showing infiltration of pancreatic acini by melano macrophage (MMC). $\mathrm{H} \& \mathrm{E}, \mathrm{x} 60$.

Fig. 7: O. niloticus infected with $A$. hydrophila, kidney showing severe hyaline droplets degeneration. $\mathrm{H} \& \mathrm{E}, \mathrm{x} 150$.

Fig. 8: 0 . niloticus infected with $A$. hydrophila, kidney showing coagulative necrosis of renal tubules. $\mathrm{H} \& \mathrm{E}, \mathrm{x} 150$. 

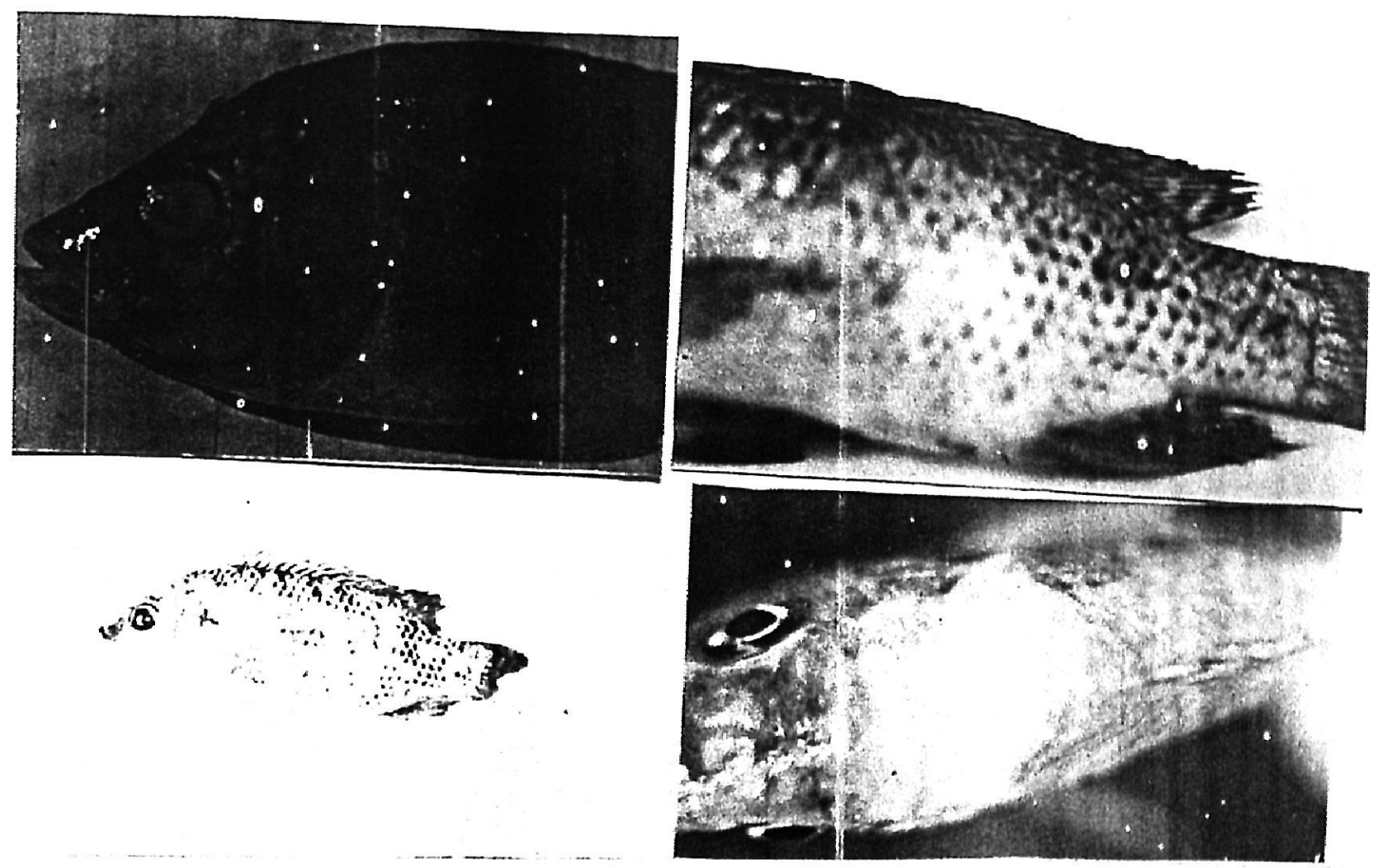

Fig (1)

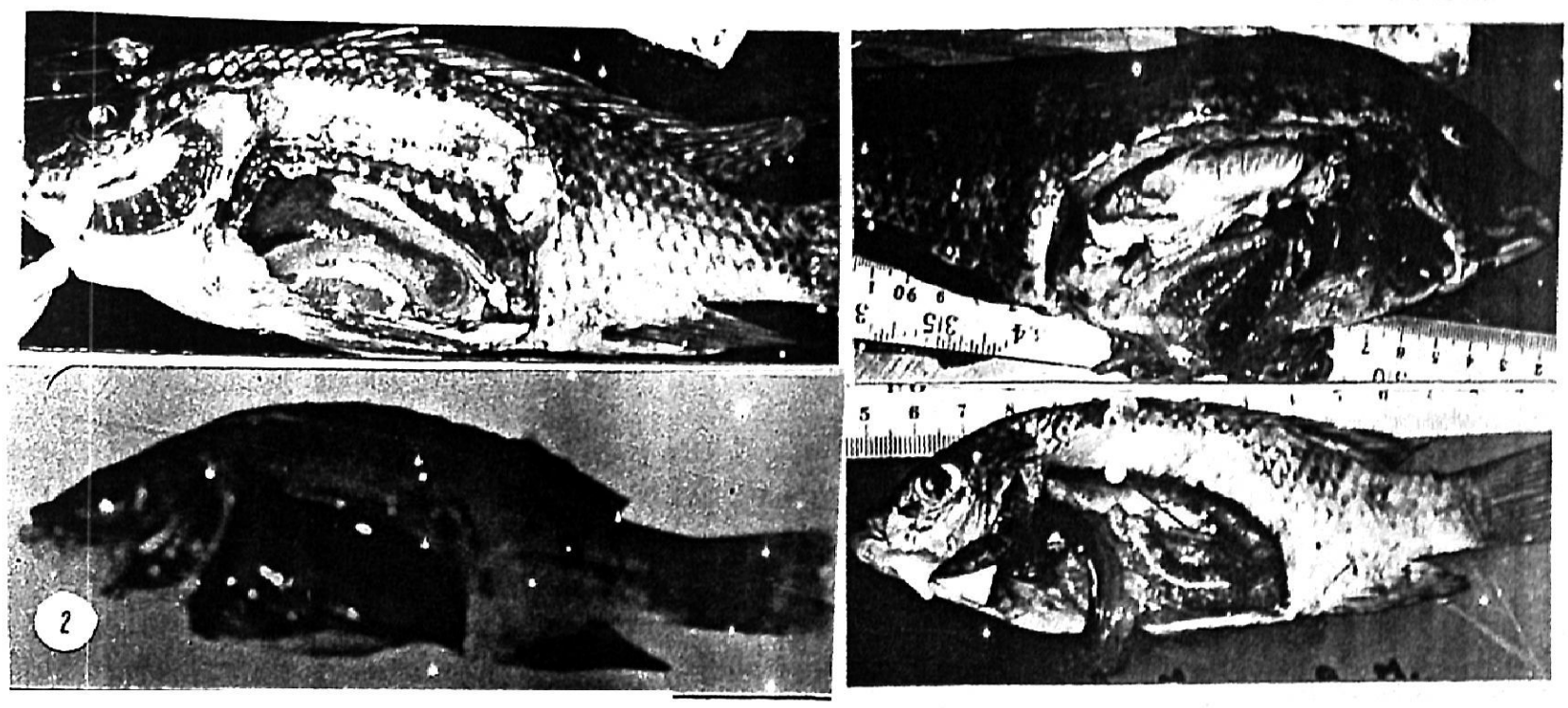

Fig (2) 


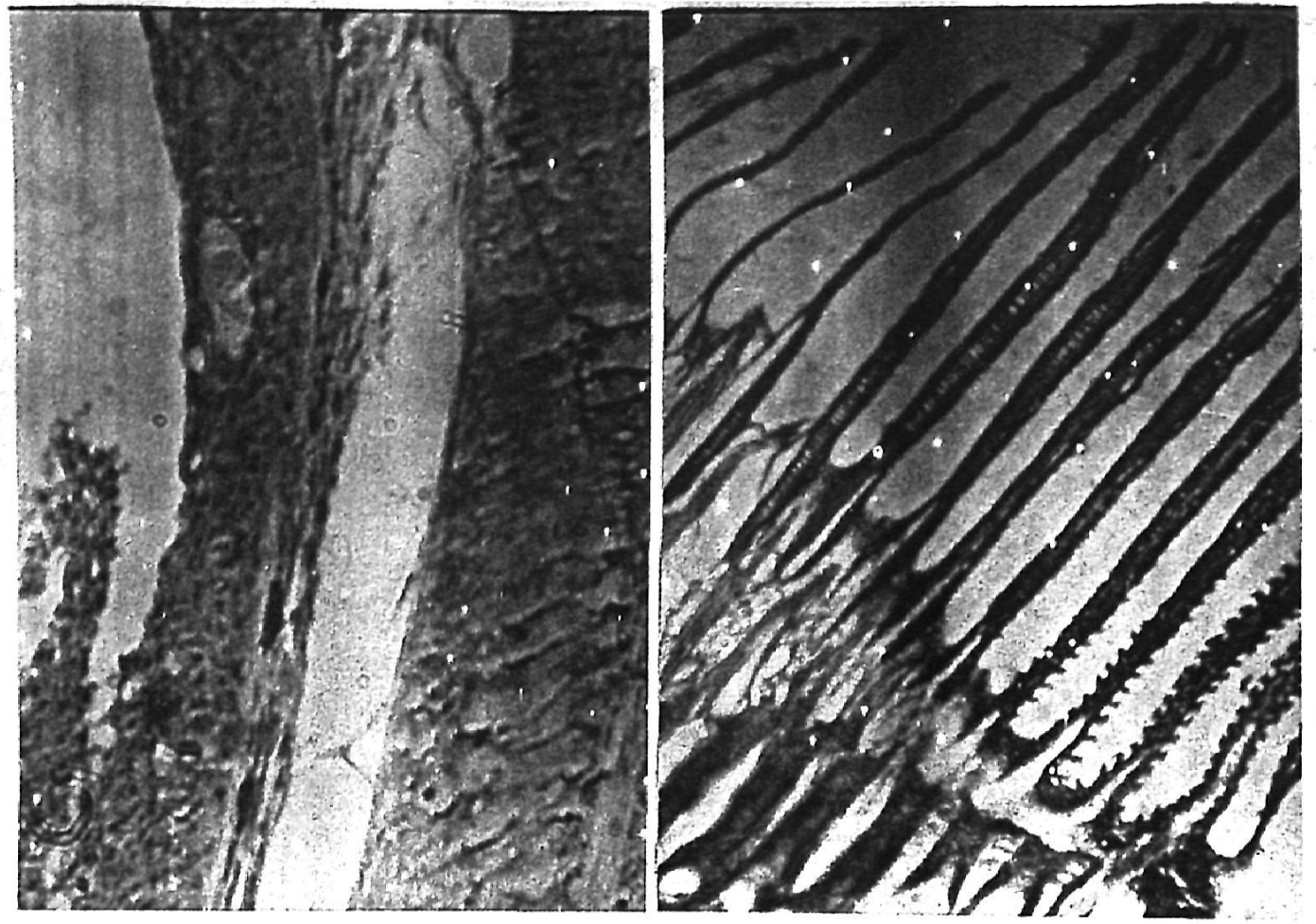

Fig (3)

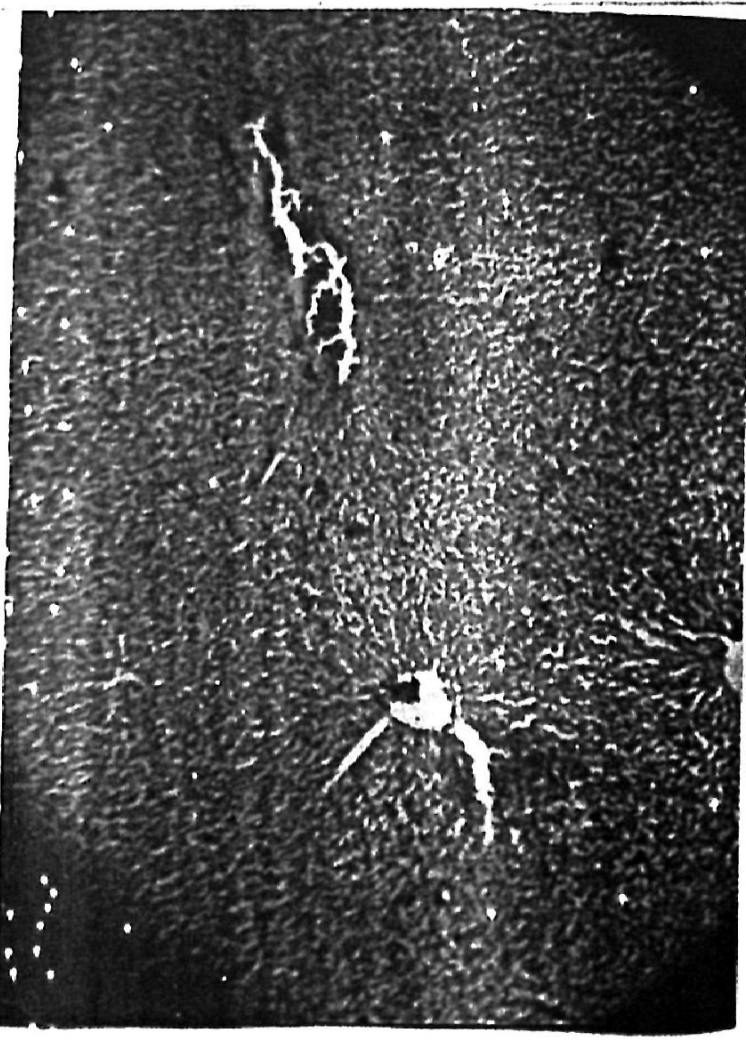

Fig (5)
Fig (4)

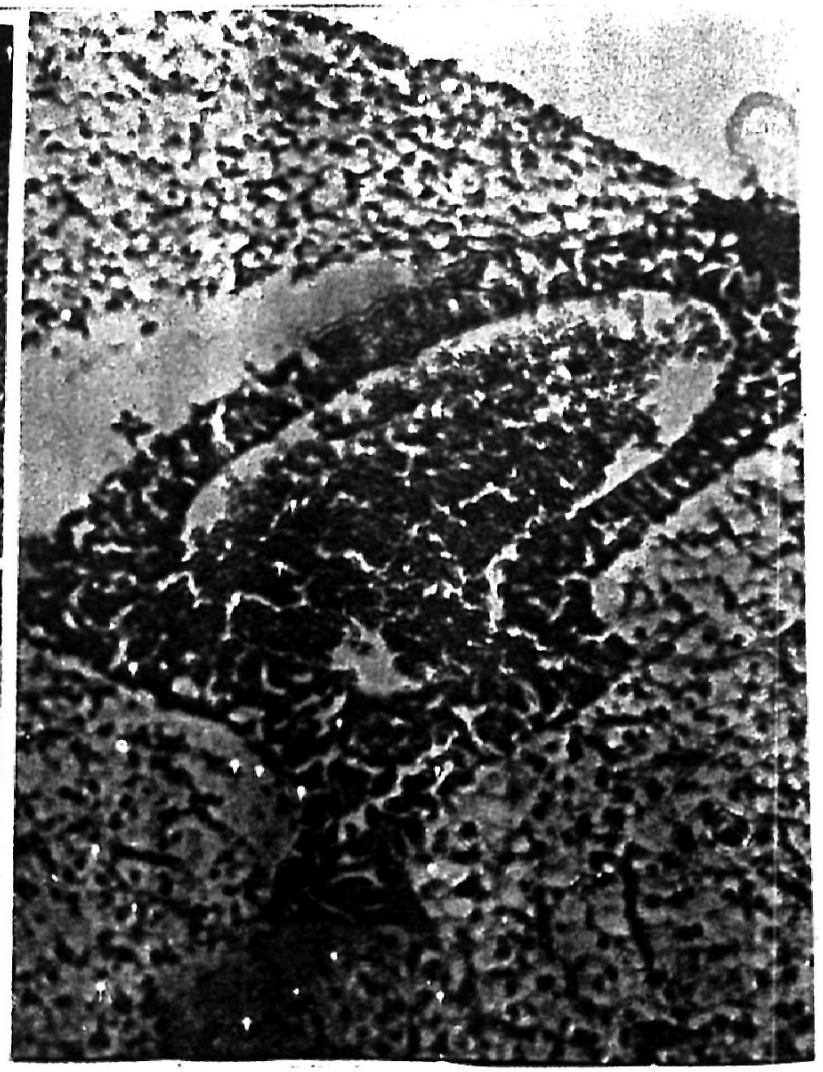

Fig (6) 


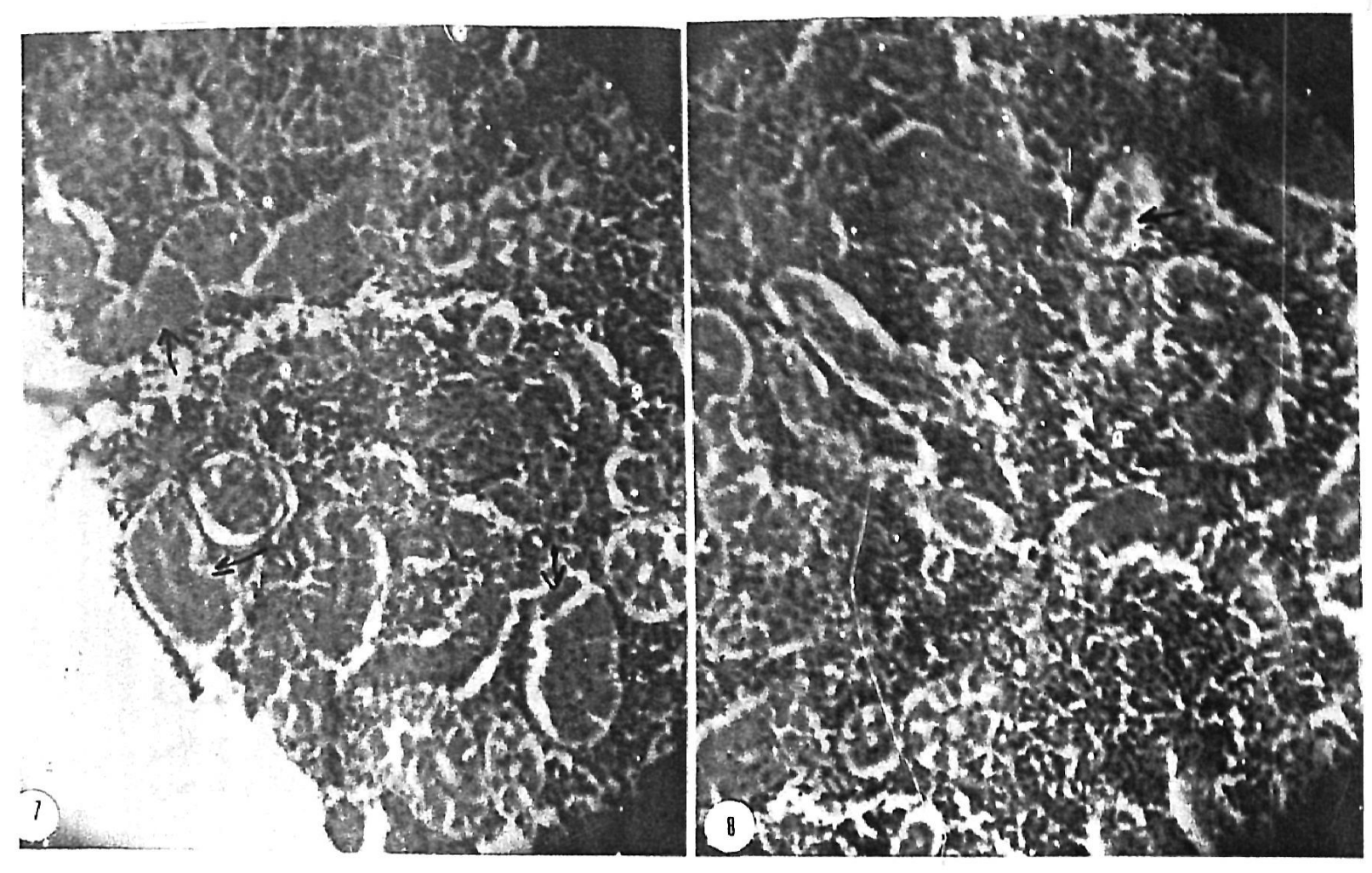

Fig (7)

Fig (8) 